\title{
Efektivitas Perluasan Aspek Pasar dan Pemasaran pada Startup Dodolan Ingsun
}

Nur Aini Azizah ${ }^{1}$, Nurleila Jum'ati ${ }^{2}$, Mutiara Sabrinda $^{3}$, Siti Nurfadilah $^{4}$, Adi Kurniawan
,

ainipunyaaivi@gmail.com,nurleila@uwp.ac.id, sabrie333@gmail.com,nurfadilahs501@gmail.com, adi256980@gmail.com,agustinustri12081996@gmail.com

\begin{abstract}
Abstrak
Dodolan Ingsun merupakan startup berbasis sociopreneur yang memberdayakan UMKM peternak bebek, pengrajin telur asin dan kerupuk kupang yang berada di Candi, Sidoarjo. Permasalahan yang dihadapi yaitu belum melakukan inovasi produk baru, dan pemasaran yang dilakukan dengan metode konvensional sehingga omzet penjualan cenderung menurun. Dengan permasalahan tersebut maka startup Dodolan Ingsun melakukan perluasan aspek pasar dan pemasaran dengan cara mengembangkan inovasi produk baru, mengembangkan pemasaran konvensional ke segmen yang lebih luas, masuk ke pemasaran non konvensional melalui pengembangan media sosial, membangun website. Hasil penerapan startup berbasis sociopreneurship adalah : 1) varian produk lebih variatif yaitu produk : telur asin mentah, botok telur asin, kerupuk kupang goreng dengan cocolan petis dan kerupuk kupang goreng pasir, 2) Penjualan secara online di : website Dodolan Ingsun, media sosial ( instagram, whatsapp), 3) penjualan secara offline : Edu Cafe, Kantin Kampus 2 Wiyung, 4) mengikuti pameran untuk pengenalan produk, 5) keluarnya SIUP, 6) Desain industri untuk kemasan ramah lingkungan baru untuk produk telur asin. Dari tahapan yang telah dijalankan startup Dodolan Ingsun mengalami peningkatan pedapatan hal tersebut sangat berpengaruh terhadap kestabilan produksi dan penjulan produk yang dihasilkan mitra, sehingga mampu menjadi wadah perputaran ekonomi yang hasilnya dapat dinikmati oleh semua pihak yang terlibat.
\end{abstract}

Kata kunci : dodolan ingsun, sociopreneur, aspek pasar, dan pemasaran.

\section{PENDAHULUAN}

Dodolan Ingsun merupakan startup berbasis sociopreneur untuk meningkatkan kualitas insan Indonesia melalui asupan protein hewani yang bertujuan untuk memperoleh profit, Dalam hal ini Startup sendiri memiliki definisi yaitu perusahaan yang dirintis atau dirancang untuk menemukan model bisnis yang tepat untuk perusahaannya sehingga diharapkan dapat bertahan ditengah ketidakpastian yang ekstrem hal ini dijelaskan oleh Jaya (2017) dalam penelitian tersebut juga dijelaskan ada lima faktor yang harus diperhatikan oleh startup baru lima, faktor tersebut adalah timing, team, idea, bisnis model dan funding. Dalam menjalankan bisnis tim Dodolan Ingsun berusahan memenu faktor-faktor yang menjadi penunjang keberlanjutan usaha tersebut.

Startup Dodolan Ingsun bekerjasama dan memberdayakan mitra UMKM peternak bebek, pengrajin telur asin dan pengrajin kerupuk kupang. Mitra UMKM tersebut berdomisili di Desa Kebonsari, Kecamatan Candi, Kabupaten Sidoarjo. Sehingga unit usaha ini disebut sebagai Startup Dodolan Ingsun dengan sistem kerja bebasis sociopreneur, menurut Nicholls (2008) konsep sociopreneur yang dapat diartikan bahwa bila dilihat dari suku katanya adalah dari dua suku kata yaitu social dan eterpreneur. Sehingga makna pemahaman Sociopreneur dapat diartikan sebagai kewirausahaan yang mengatasi permasalahan sosial dilihat dari dua suku kata yaitu sosial dari kewirausahaan yang medasari makna tersebut.

$$
\text { Ekonomi, Sosial, dan Budaya }
$$


Agustina (2011) menyimpulkan kompetensi dalam sociopreneurs yaitu harus membantu menyelesaikan permasalahan sosial. Kompetensi sesociopreneur ini diharapakan menyelesaikan masalah dengan mengubah sistem, menyebarkan solusi dan meyakinkan orang lain untuk ikut terlibat dalam melakukan dan dapat membawa perubahan yang lebih baik hal tersebut menjadi salah satu dasar untuk Startup Dodolan Ingsun bermitra dengan UMKM peternak bebek, pengrajin telur asin dan pengrajin kerupuk kupang dikarenakan hasil survey yang dilakukan tim mitra tersebut mengalami kesulitan penjulan produk sehingga barang yang diproduksi mengalami penumpukan stock dan membuat mereka berheti beberapa saat untuk tidak berproduksi hingga stock barang lama terjual.

Untuk domisili Startup Dodolan Ingsun sendiri ada di Jl. Raya Kendung Gang 1 nomor 14 Surabaya Barat sehingga Startup Dodolan Ingsun memiliki target wilayah penjualan saat ini yaitu di daerah Surabaya Barat yang meliputi kecamatan Benowo, kecamatan Pakal, kecamatan Asemrowo, kecamatan Sukomanunggal, kecamatan Tandes, kecamatan Sambikerep, dan kecamatan Lakarsantri. Pengembangan daerah pemasaran Startup Dodolan Ingsun juga meliputi wilayah Gresik Selatan yaitu kecamatan Duduk Sampean, kecamatan Cerme, kecamatan Benjeng, kecamatan Balong Panggang, kecamatan Menganti, kecamatan Kedamean, kecamatan Driyorejo, dan kecamatan Wringin Anom. Dengan varian produk yang dijual yaitu : Telur asin kukus, asap, dan oven juga kerupuk kupang goreng minyak merupakan produk yang telah diproduksi Dodolan Ingsun selama ini. Kuantitas produksi dari mitra Dodolan Ingsun semakin tinggi. Hal tersebut menyebabkan beberapa telur asin mengalami keretakan dalam proses pengeraman atau pengasinan. Tingginya kuantitas yang diproduksi kurang diimbangi dengan banyaknya produk yang terjual. Hal tersebut terjadi karena mitra dari Dodolan Ingsun hanya menggunkan sistem penjualan konvensional yaitu bertemu langsung dengan customer ditoko.

Untuk memperbaiki kelemahan tersebut maka Startup Dodolan Ingsun melakukan perluasan aspek pasar dan pemasaran. Hal tersebut didukung oleh penelitian yang dilakukan oleh Saniya (2015) bahwa pemasaran online atau internet marketing, memiliki cakupan yang cukup luas termasuk e-mail marketing, electronic customer relationship management dan aktifitas promosi lain melalui wireless media. Dalam upaya memperluas aspek pasar dan pemasaran, Startup Dodolan Ingsun melakukan inovasi. Menurut hasil penelitian Romdonah (2015) tentang pengaruh inovasi produk, harga dan brand image terhadap keputusan pembelian sepeda motor honda beat (studi kasus pada konsumen dealer honda pratama kurnia kasih) menunjukkan bahwa apabila produk yang ditawarkan semakin bervariasi maka keputusan pembelian akan semakin meningkat. Dengan demikian maka upaya Startup Dodolan Ingsun dalam memperluas aspek pasar dan pemasaran melalui inovasi produk, kemasan, dan promosi perlu dilaksanakan dengan harapan bahwa omset yang diperoleh akan meningkat.

Faktor lain yang bepengaruh terhadap peningkatan omset dari Startup Dodolan Ingsun adalah penetuan harga dari varian produk yang dijual dengan memperhitungkan segala jenis biaya yang mempengaruhi tetapi tidak melupakan perhitungan benefit yang harus diterima. Seperti yang dijelaskan oleh Rhenald Kasali (2010 : 243) "Meperbaiki struktur biaya melalui proses produksi, efisiensi, cara-cara baru, IT, itegrasi sistem, dan sebagainya" dalam penjelasan tersebut valeue cereation sangat mempengaruhi perhitungan untuk pentuan seberapa besar cost dan benefit yang akan diperoleh dari penjulan produk Startup Dodolan Ingsun untuk terus berkembang.

\section{METODE}

Berdasarkan penjabaran sebelumnya mengenai identifikasi permasalahan dan skala prioritas masalah yang akan diselesaikan tidak menurut penilaian subyektifitas tim penyusun, namun ditentukan oleh dasar kesepakatan bersama. Hal ini dimaksudkan agar pemilihan solusi yang akan digunakan Startup Dodolan Ingsun benarbenar efektif. Metode yang dilakukan Startup Dodolan Ingsun, melalui beberapa tahapan seperti tertera pada flowchart dibawah ini:

Ekonomi Sosial dan Budaya

1074 


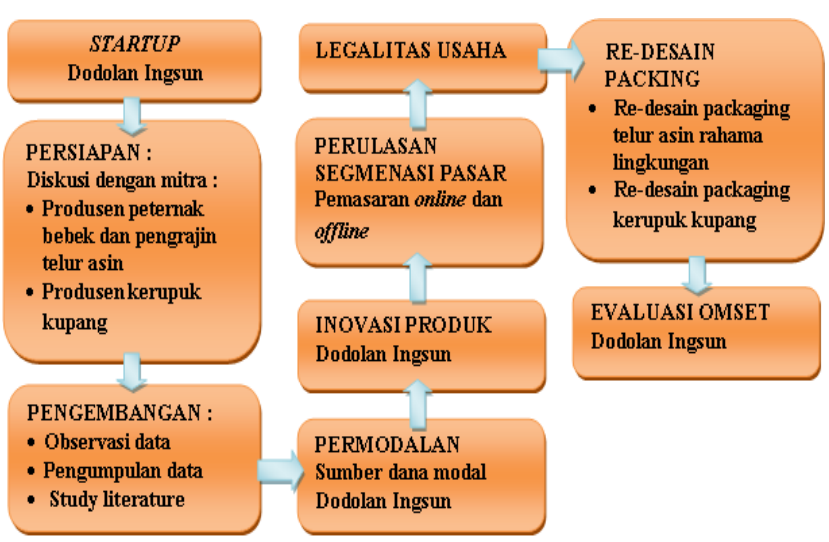

Gambar 1. Diagram Alir Metode Pelaksanaan

Berdasarkan gambar diatas, maka dapat diketahui bahwa tahapan yang dilakukan sebagai berikut : 1) persiapan Tim Dodolan Ingsun mengunjungi mitra UMKM peternak bebek, pengrajin telur asin dan kerupuk kupang yang berada di Candi Sidoarjo untuk observasi. 2) pengembangan Dari pengumpulan data yang dilakukan oleh Startup Dodolan Ingsun diperoleh permasalah sebagai berikut : a) Beberapa telur asin yang retak pada proses pengeraman atau pengasinan. b) Pemasaran masih menggunakan cara konvensional. c) Kurangnya inovasi produk. d) Kurang mendukungnya packaging produk. Untuk mengolah data yang diperoleh Startup Dodolan Ingsun menggunakan kajian literatur berupa jurnal ilmiah, skripsi, prosiding seminar dan buku agar dapat menetukan langkah selajutya yang akan diambil. 3) Permodalan menurut penelitian yang dilakukan oleh Nayaka (2018) yang menyatakan bahwa modal berpengaruh positif dan signifikan terhadap pendapatan. Sehingga dapat dikatakan modal berperan penting dalam pengembangan usaha guna menaikkan pendapatan. Dari hasil penelitian tersebut maka Startup Dodolan Ingsun melakukan penambahan modal untuk pengembangan usahanya. 4) Inovasi produk yaitu peningkatan penjualan ditentukan oleh tingginya keputusan pembelian produk oleh konsumen. Hal tersebut selaras dengan penelitan yang dilakukan oleh Setiawan (2018) yang menyatakan bahwa inovasi produk berpengaruh signifikan terhadap keputusan pembelian produk.

Oleh karena itu untuk menunjang perluasan aspek pasar dan pemasaran demi terjadinya kenaikan penjualan, maka Dodolan Ingsun melakukan inovasi produk dengan menambahkan varian dan memperbaiki produk yang sudah ada. 5) Perluasan aspek pasar dan pemasaran Menurut Setiawati (2017) yang melakukan penelitian mengenai pengaruh strategi pemasaran online terhadap peningkatan laba UMKM menyimpulkan bahwa strategi pemasaran online berpengaruh positif terhadap laba Usaha Mikro Kecil dan Menengah (UMKM). Melihat hal tersebut Startup Dodolan Ingsun memperluas pemasarannya melalui digital marketing dengan membuat website dan media sosial (instagram dan whatsapp). Walaupun pemasaran Startup Dodolan Ingsun telah diperluas melalui digital marketing, pemasaran secara konvensional pun tetap dilakukan, namun dengan penambahan mitra bisnis dan juga aktif mengikuti pameran dan bazar di Surabaya. Hal tersebut didukung oleh penelitian yang dilakukan Agusetyaningrum (2016) yang menyatakan bahwa pameran dan media sosial merupakan teknik pemasaran yang sangat membantu pelaku UMKM. 6) Legalitas usaha Peraturan Menteri Perdagangan No. 289/MPP/Kep/10/2001 tentang penerbitan Surat Izin Usaha Perdagangan (SIUP) pasal 2 ayat 1 sampai dengan ayat 3 menerangkan bahwa "setiap usaha wajib memiliki SIUP. SIUP terdiri dari SIUP kecil, SIUP menengah, dan SIUP besar. Selain SIUP tersebut, juga dapat diberikan SIUP mikro kepada perusahaan perdagangan mikro". Startup Dodolan Ingsun mendaftar izin usaha untuk memeperoleh SIUP pada tanggal 30 Juli 2019.

Setelaha kita melalui beberapa tahapan dan evaluasi perlunya dilakukan re-desain packaging, 7) $\mathrm{Re}$ - desain packaging Menurut penelitian terdahulu oleh Njoto (2018) menyatakan bahwa desain kemasan produk berpengaruh signifikan terhadap keputusan pembelian konsumen. Selama ini Startup Dodolan Ingsun mengemas telur asin dengan wadah plastik telur yang ada di pasaran. Namun packaging tersebut memiliki kelemahan-kelamahan yang tidak mendukung kualitas produk Dodolan Ingsun. Oleh karena itu tim Dodolan Ingsun melakukan re-desain packaging sesuai dengan kondisi produk yang lebih eye cathcing dan ramah lingkungan. 8) Evaluasi omset Dodolan Ingsun berdasarkan pengamatan dengan pertimbangan valeue cereation dengan memperhatikan perhitungansebagi berikut :

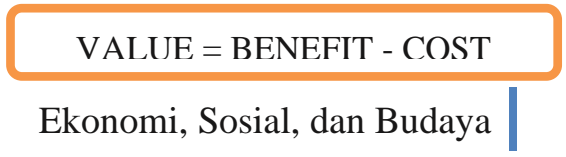


Hal tersebut diungkapakan oleh Kasali (2010 : 243) sehingga dapat diketahui langkahlangkah yang telah dijalankan telah efisien dan menciptakan value yang dapat maeningkatkan benefit, Untuk tahap pelaporan setiap kegiatan yang dilakukan oleh tim Startup Dodolan Ingsun mulai dari persiapan, pelaksanaan dan evaluasi dilaporkan dalam tulisan dan terdokumentasi.

\section{HASIL DAN PEMBAHASAN}

\section{Tahap 1. Persiapan}

Tahap persiapan dilakukan oleh tim mulai dari survey lokasi Usaha Mikro Kecil dan Menengah (UMKM) peternak bebek, pengrajin telur asin dan kerupuk kupang yang berada di Candi Sidoarjo. Untuk mengetahui permasalahan dari mitra yaitu berkaitan dengan penumpukan produksi karena kurang tepat sistem pemasaran produk sehingga tim membuat sebuah bisnis yang diberi nama Startup Dodolan Ingsun dengan konsep tim mendapatkan untung dan mitra pun mendapatkan untung.
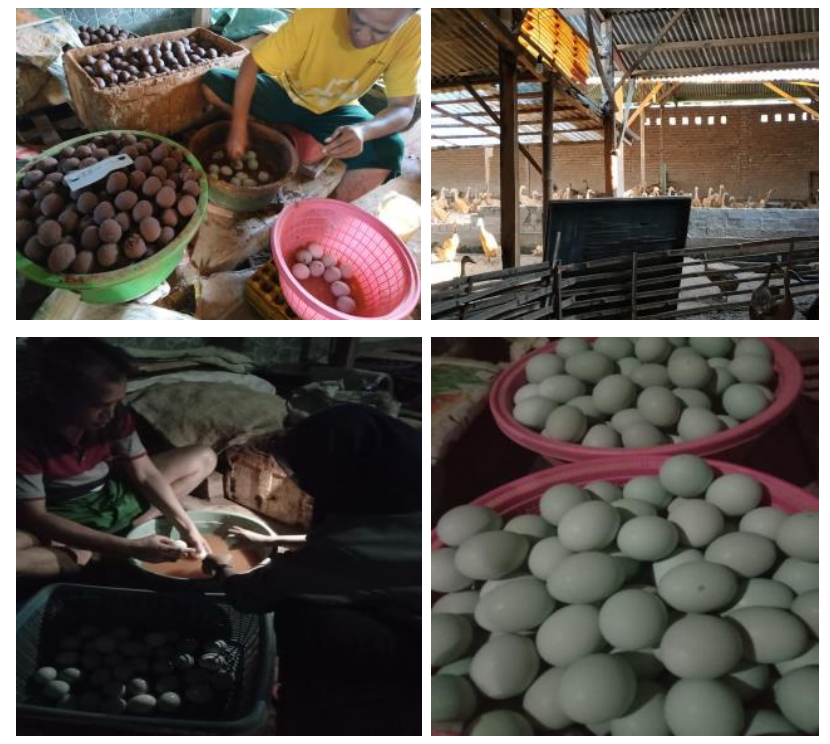

Gambar 2. Dokumentasi survey lokasi Mitra dari Startup Dodolan Ingsun

Adapun data permasalahan utama yang dialami oleh mitra sebagai berikut :

1. Penumpukan hasil produksi karena tidak seimbang antara hasil produksi dengan kapasitas penjualan.
2. Produk yang dihasilkan berkualitas tinggih dikarenakan proses dari pakan ternak hingga pengasinan sangat diperhatikan sehingga harga jual yang relative lebih tinggi dari pada pasaran.

3. Sengmentasi pasar untuk penjulan produk masih tergolong kecil dan kurang luas

dari data-data yang diperoleh dari hasil survey tersebut menunjang dalam proses selanjutnya.

\section{Tahap 2. Pengembangan}

Berdasarkan data yang telah dikumpulkan oleh tim Dodolan Ingsun diperoleh hal-hal yang menjadi fokus utama untuk diselsaikan yaitu : 1) Permodalan untuk mebangun Startup Dodolan Ingsun, 2) Inovasi produk agar dapat diterima pada segmentasi pasar yang akan dituju, 3) Perluasan aspek pemasaran dari Startup Dodolan Ingsun dengan cara digital marketing dan perbaikan sistem penjualan secara konvensional yang akan dijelaskan pada tahap 5 berkaitan dengan perluasan aspek pemasaran, 4) Pembuatan legalitas usaha yang menjadi identitas dari Startup Dodolan Ingsun. Dengan menetukan tahap-tahap pengembangan ini diharapkan memberikan dampak positif bagi UMKM peternak bebek, pengrajin telur asin dan kerupuk kupang dengan harapan terjadi peningkatan penjulan secara signifikan, sehingga hal tersebut juga mempegaruhi peningkatan omset dari Startup Dodolan Ingsun sendiri.

\section{Tahap 3. Permodalan}

Dalam sebuah usaha perencanaan pengalokasian modal dan manajemen keuangan dituntut untuk mapu melakukan efisiensi semua itu dapat diwujudkan dengan menarik suatu keputusan dalam kebijakan untuk menentukan modal yang dibutuhkan hal tersebut disampikan dalam penelitian Sukoco (2015). Sehingga berjalannya usaha Startup Dodolan Ingsun tidak lepas dari pendanaan untuk menunjang operasional serta permodalan untuk pengembangan usaha, maka dari itu Startup Dodolan Ingsun memiliki beberapa sumber dana, pada saat membuka usaha modal adalah hasil patungan dari anggota pada bulan November tahun 2018 kemudian dibulan Juli 2019 ada investor ingin menanam modal pada Startup Dodolan Ingsun.

Terlepas dari dua pendanaan tersebut anggota tim melakukan berbagai usaha untuk menambah modal dengan cara mengajukan beberapa proposal pendanan usahan, Kemudian di

$$
\text { Ekonomi Sosial dan Budaya } 1076
$$


akhir bulan juni 2019 tim menerima surat keputusan bawah proposal yang diajukan pada bulan maret 2019 lolos didanai untuk pengembangan usaha. Untuk data permodala Startup Dodolan Ingsun diuraikan pada tabel berikut :

Tabel 1. Tabel sumber dana Startup Dodolan Ingsun

\begin{tabular}{|c|c|c|}
\hline Sumber Dana & Prosentase & Fungsi dari Pendanaan \\
\hline $\begin{array}{l}\text { Modal Awal Anggota Tim: } \\
\text { 1. Nur Aini Azizah } \\
\text { 2. Agus Tinus Trihatmoko } \\
\text { 3. Adi Kurniawan } \\
\text { 4. Muatiara Sabrinda } \\
\text { 5. Siti Nurfadilah }\end{array}$ & $19 \%$ & $\begin{array}{l}\text { Modal awal pembentukan } \\
\text { usaha untuk meingikat } \\
\text { komitmen dalam tim } \\
\text { Dodolan Ingsun pada } \\
\text { bulan November } 2018\end{array}$ \\
\hline $\begin{array}{l}\text { Pemnabahan Modal Investor: } \\
\text { 1. Ayu Asmaul } \\
\text { 2. Risca Rahmania }\end{array}$ & $7 \%$ & $\begin{array}{l}\text { Penambahan Modal dari } \\
\text { Investor di Bulan Juli }\end{array}$ \\
\hline 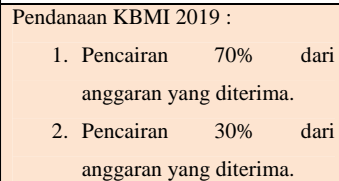 & $74 \%$ & \begin{tabular}{llr}
\multicolumn{2}{l}{ Pendanaan } & dari \\
RISTEKDIKTI & dari \\
program & KBMI 2019 \\
untuk & pengembangan \\
usaha &
\end{tabular} \\
\hline
\end{tabular}

Dari data perosetase permodalan yang di terima Startup Dodolan Ingsun sejak tahun 2018 hingga tahun 2019 merupakan dana penunjang operasional untuk pengembangan usaha .

\section{Tahap 4. Inovasi Produk}

Keretakan telur asin dalam proses pengasinan dan pengasapan diubah oleh tim Dodolan Ingsun menjadi sebuah peluang untuk memperluas pasar dengan membuat inovasi produk, yaitu Botok Telur Asin ready to eat. Hal tersebut telah disampikan ke mitra dengan pendampingan mitra pun dapat memproduksi varian baru tersebut. Tidak berhenti disitu tim Dodolan Ingsun juga memasarkan telur asin mentah untuk customer pengolah, kerupuk kupang dengan sambal petis yang dibungkus menggunakan plastik zipper alumunium yang dimasukana pada kemasan varian tersebut terinspirasi dari customer penikmat makanan bercita rasa pedas, kerupuk kupang goreng pasir untuk customer yang menerapkan gaya hidup sehat dan juga penderita kolestrol dan darah tinggi.

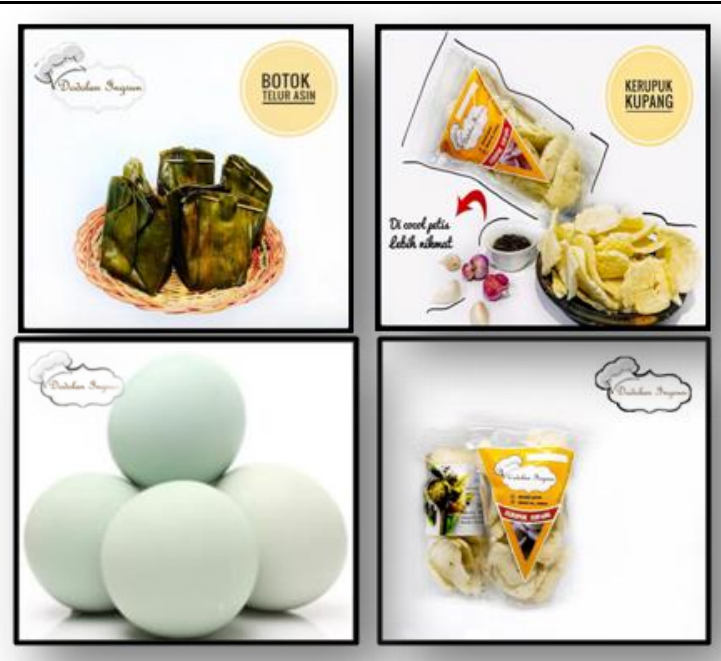

Gambar 3. Varian produk inovasi Startup Dodolan Ingsun

\section{Tahap 5. Perluasan Aspek Pemasaran}

Tim Dodolan Ingsun menambah sistem pemasarannya yang semula secara konvensional kini mulai menggunakan digital marketing untuk memperluasan jangkauan pemasaran dan pengenalan produk. Melalui web Dodolan Ingsun (https://sites.google.com/view/dodolaningsun/hom), instagram (@dodolan_ingsun), dan whatsapp. Untuk menarik minat konsumen Tim Dodolan Ingsun melakukan sistem give away dan update promosi dan perkembangan di story setiap social media.

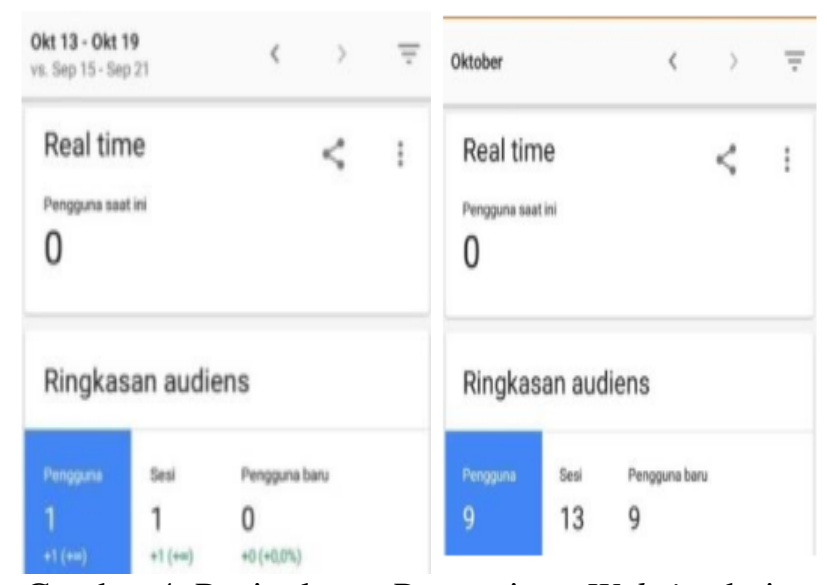

Gambar 4. Peningkatan Pengunjung Website dari Bulan September ke Oktober 2019 


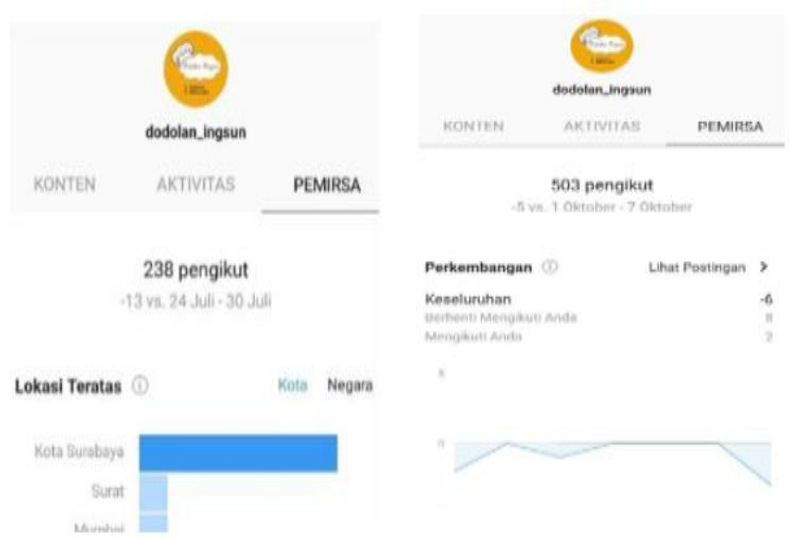

Gambar 5. Peningkatan Pengunjung Instagram dari Bulan Juli ke Bulan Oktober 2019

Dari gambar 4 menunjukkan bahwa terjadi peningkatan pengunjung pada situs website Dodolan Ingsun. Peningkatan juga terlihat pada akun Instagram Dodolan Ingsun. Kenaikan pengunjung tersebut juga mempengaruhi omzet yang didapat. Penjualan secara konvensional pun tidak dilupakan oleh Startup Dodolan Ingsun. Dalam konsep kemitraan, Dodolan Ingsun merupakan sebuah usaha yang di bentuk dengan konsep entitas sociopreneur dimana juga supplier sebagai mitra bisnis. Selain mitra bisnis untuk pemenuhan produk Dodolan Ingsun sebagai supplier, tim memiliki mitra bisnis lain dengan tujuan untuk memperluas pasar sehingga tim melakukan konsiniyasi dengan beberapa tempat untuk dijadikan mitra bisnis yaitu : 1) Edu Cafe (Koperasi GDK) Universitas Wijaya Putra, Kampus 1 (Benowo). 2) Kantin Universitas Wijaya Putra, Kampus 2 (Wiyung). 3) Reseller baik secara pribadi maupun kerjasama dengan catering. Mengikuti bazar dan pameran juga menjadi cara untuk memperluas pasar dan mempercepat penjualan produk. Beberapa bazar dan pameran yang diikuti oleh tim Dodolan Ingsun, yaitu seperti table dibawah ini :

\section{Tabel 2. Pameran Yang Diikuti Oleh Startup} Dodolan Ingsun

\begin{tabular}{|c|l|l|}
\hline No & \multicolumn{1}{|c|}{ Tempat } & \multicolumn{1}{c|}{ Tanggal } \\
\hline 1. & Bazar ECOFEST di Universitas Wijaya Putra & 12 Juli 2019 \\
\hline 2. & Bazar di GOR Petro Gresik & 21 - 27 Juli 2019 \\
\hline 3. & berjualan di Taman Cahaya Pakal & 04 Agustus 2019 \\
\hline 4. & pameran di Hotel Vasa Surabaya & 10 Agustus 2019 \\
\hline 5. & berjualan di Taman Bungkul Surabaya & 25 Agustus 2019 \\
\hline 6. & Pameran Seminar Investasi di Kuno Kini Resto Surabaya & 27 September 2019 \\
\hline 7. & Pameran Konferensi Nasional ke - 5 PKM CSR & 23 - 24 Oktober 2019 \\
\hline
\end{tabular}

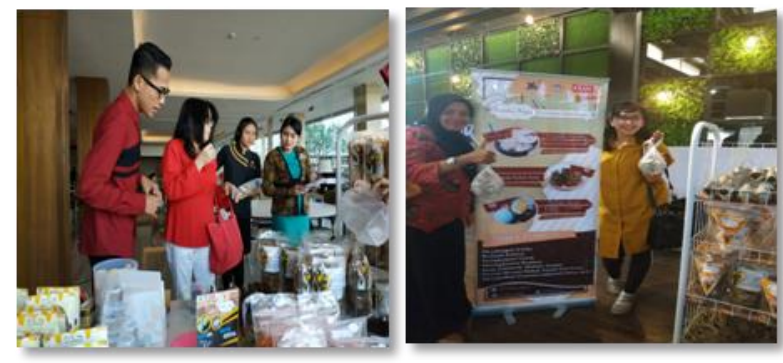

Gambar 5. Dokumentasi kegitan pameran kewirausahaan yang diikuti Startup Dodolan Ingsun

\section{Tahap 6. Legalitas Usaha}

Dodolan Ingsun sebagai unit usaha perdagangan telah memperoleh SIUP sesuai dengan Peraturan Menteri Perdagangan yaitu pada No.289/MPP/Kep/10/2001. Hal tersebut mendukung untuk memperkuat kepercayaan konsumen kepada Startup Dodolan Ingsun karena sudah mempunyai legalitas hukum. Startup Dodolan Ingsun mendaftar izin usaha untuk memeperoleh SIUP pada tanggal 30 Juli 2019. SIUP Dodolan Ingsun terbit pada tanggal 12 Agustus 2019.

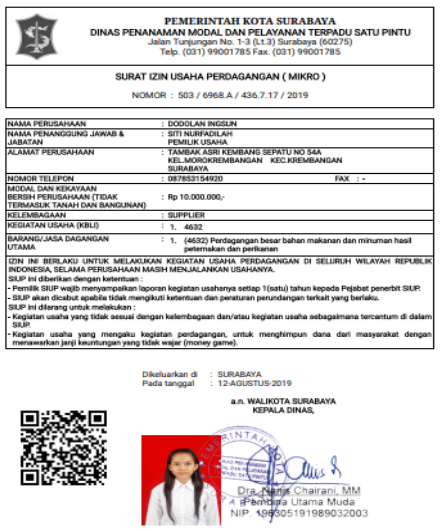

Gambar 6. Legalitas SIUP

\section{Tahap 7. Re - desain packaging}

Produk telur asin awalnya dikemas dengan plastik namun kemasan tersebut memiliki kekurangan yaitu tidak ramah lingkungan, ukuran telur terlalu besar dibandingkan plastik yang ada dipasaran, plastik dipasaran cenderung tipis sehingga mudah sobek. Untuk packaging kerupuk kupang juga memiliki kekurangan yaitu plastic yang digunakan terlalu tipis dan tembus pandang

$$
\text { Ekonomi Sosial dan Budaya }
$$


sehingga produk lebih cepat menjadi tidak renyah. Kekurangan-kekurangan tersebut.
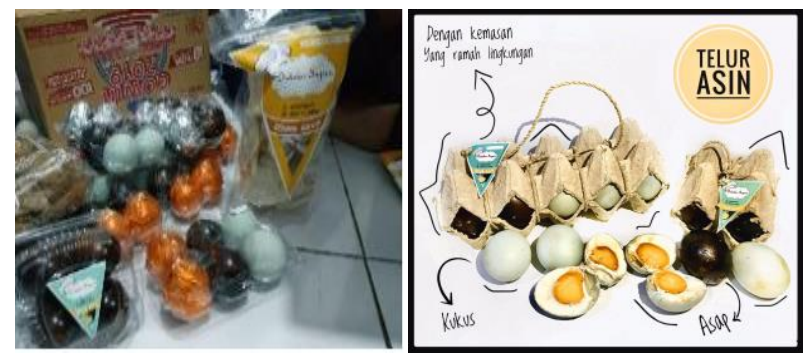

Gambar 7. Packaging sebelum dan sesudah diinovasi

Menekan perluasan aspek pasar Dodolan Ingsun, maka Dodolan Ingsun membuat inovasi packaging yang lebih eye catching dan ramah lingkungan. Produk telur asin yang semula dikemas menggunkan plastik kini dikemas menggunakan tray telur dan menggunakan ikat tali jerami sehingga menjadi lebih ramah lingkungan, sedangkan produk kerupuk kupang dikemas dengan packaging plastik yang modern.

\section{Tahap 8. Evalusi Omset}

Pengaruh aspek perluasan pasar dan pemasaran pada startup Dodolan Ingsun selain berdampak pada peningkatan pengunjung online juga berpengaruh terhadap omzet. Dapat dilihat dari data pendapatan yang diperoleh periode Bulan Juni 2019 hingga Bulan Oktober 2019 sebagai berikut :

Tabel 2. Tabel data omset Startup Dodolan Ingsun \begin{tabular}{|l|l|l|l|l|}
\hline Juni 2019 & Juli 2019 & Agustus 2019 & September 2019 & Oktober 2019 \\
\hline Rp & & \\
\hline
\end{tabular} \begin{tabular}{|ll|ll|ll|ll|ll|}
\hline $\mathrm{Rp}$ & $3,560,000$ & $\mathrm{Rp}$ & $3,355,000$ & $\mathrm{Rp}$ & $4,700,000$ & $\mathrm{Rp}$ & $5,670,000$ & $\mathrm{Rp}$ & $7,725,000$ \\
\hline
\end{tabular}

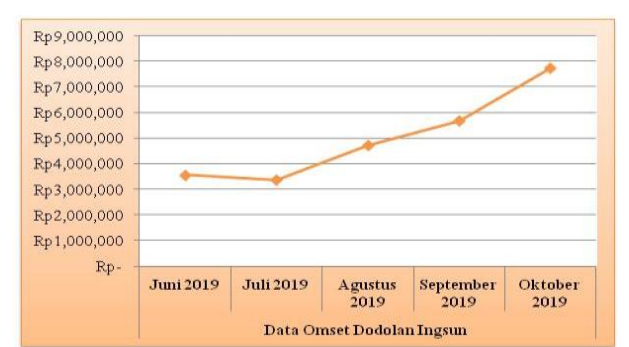

Gambar 8. Grafik peningkatan omset Startup Dodolan Ingsun

setelah perluasan aspek pasar dan pemasaran dilakukan. Perkembangan Omzet Dodolan Ingsun Berdasarkan data tersebut dapat disimpulkan bahwa omzet Startup Dodolan Ingsun meningkat setelah pengadaan perluasan aspek pasar dan pemasaran mengalami kenaikan dibandingkan dengan sebelumnya. Hal ini juga berpengaruh dengan ketabilan stock produksi mitra yaitu berkurangnya penumpuka stock barang yang telah diproduksi karena penjulan mualai stabil, hal itu dibuktikan dengan data hasil produksi dan penjulan tahun 2019 sebagai berikut :

Tabel 3. Tabel data produksi UMKM Telur Asin

\begin{tabular}{|c|c|c|}
\hline \multirow{2}{*}{ B ulan } & Hasil Produksi & Penjualan \\
\cline { 2 - 3 } & Satuan Butir & Satuan Butir \\
\hline Januari & 750 & 470 \\
\hline Februari & 700 & 500 \\
\hline Maret & 600 & 505 \\
\hline April & 625 & 600 \\
\hline Mei & 800 & 700 \\
\hline Juni & 850 & 700 \\
\hline Juli & 900 & 850 \\
\hline Agustus & 1000 & 900 \\
\hline September & 1000 & 950 \\
\hline Oktober & 1150 & 1050 \\
\hline
\end{tabular}

Tabel 4. Tabel data produksi UMKM Kerupuk Kupang

\begin{tabular}{|c|c|c|}
\hline \multirow{2}{*}{ Bulan } & Hasil Produksi & Penjualan \\
\cline { 2 - 3 } & Satuan Kg & Satuan Kg \\
\hline Januari & 100 & 57 \\
\hline Februari & 100 & 85 \\
\hline Maret & 100 & 96 \\
\hline April & 100 & 67 \\
\hline Mei & 100 & 98 \\
\hline Juni & 120 & 112 \\
\hline Juli & 125 & 122 \\
\hline Agustus & 130 & 127 \\
\hline September & 150 & 120 \\
\hline Oktober & 200 & 167 \\
\hline
\end{tabular}

Kesetabilan atara produksi dan penjualan baik oleh mitra maupun dari Startup Dodolan Ingsun sendiri diharapkan menjadi wadah perputaran ekonomi yang hasilnya dapat dinikmati oleh semua pihak yang terlibat.

\section{KESIMPULAN}

Kesimpulan yang didapat dari hasil evektivitas peluasan aspek pasar dan pemasaran startup Dodolan Ingsun dengan usaha yang berbasis entitas sociopreneur antara lain 1) Penambahan

Ekonomi, Sosial, dan Budaya

1079 
permodalan membantu usaha untuk berkembang secara maksimal. 2) Pengembangan inovasi produk dapat mengurangi kerugian mitra karena produk yang rusak dalam proses produksi dapat diolah menjadi produk baru. 3) Pelusan aspek pemasran dengan sistem digital marketing dan konsiniyasi mapu mempercepat penjulan produk sehingga menguranggi permasalahan mitra prihal penumpukan hasil produksi. 4) Pembuatan legalitas usaha agar mampu menarik tingkat kepercayaan customer. Jika omset yang diterima meningkat hal tersebut juga sangat berpengaruh terhadap tingkat pendapatan mitra sehingga mampu menjadi wadah perputaran ekonomi yang hasilnya dapat dinikmati oleh semua pihak yang terlibat.

Saran : Mencari peluang untuk mengembangkan jangkaun pemasaran yang lebih luas dengan cara yang lebih inovasi dan kekinian sehingga kestabilan poduk yang diproduksi oleh maitra dapat secara continue diproduksi.

\section{UCAPAN TERIMAKASIH}

Kegiatan KBMI ini terlaksana atas pendanaan dari Kemenristekdikti tahun 2019. Untuk ucapan terima kasih disampaikan kepada : 1) Tuhan yang Maha Esa 2) Kemenristekdikti tahun 2019. 3) Rektor Universitas Wijaya Putra Surabaya, Bapak H. Budi Endarto, SH., M. Hum 4) Dekan Fakultas Ekonomi dan Bisnis Universitas Wijaya Putra Surabaya, Ibu Dr. Hj. Soenarmi, SE., MM. 5) Rekan-rekan sejawat di Universitas Wijaya Putra Surabaya 6) Bapak Musolin sebagai pemilik mitra yang turut aktif berpartisipasi dalam kegiatan.

\section{REFERENSI}

Agusetyaningrum, V., Mawardi, M. K., Pangestuti, E. 2016. Strategi Pengembangan Usaha Kecil Dan Menengah (UKM) Untuk Meningkatkan Citra Kota Malang Sebagai Destinasi Wisata Kuliner (Studi Pada UKM Berbasis Kuliner Kota Malang). Jurnal Administrasi Bisnis, 38(2): 105 111.

Agustina, C., \& Sularto, L. 2011. Intensi kewirausahaan mahasiswa (Studi perbandingan antara fakultas ekonomi dan fakultas ilmu komputer). Proceeding PESAT (Psikologi, Ekonomi, Sastra, Arsitektur, \& Sipil) Universitas Gunadarma, Depok, 18-19 Oktober 2011, 4: E.63E.69.
Kasali, Rhenald. 2010. MYELIN (Mobilisasi Intangibles Mejadi Kekuatan Perubahan). Jakarta: PT Gramedia Pustaka Utama.

Jaya, M, A., Ferdiana, R. Fauziati, S. 2017. Analisis Faktor Keberhasilan Startup Digital Di Yogyakarta. E-Jurnal Universitas Muria Kudus : 167-173, ISBN: 978-602-1180-50-1.

Nayaka, K, W., Kartika, I, N. 2018. Pengaruh Modal, Tenaga Kerja Dan Bahan Baku Terhadap Pendapatan Pengusaha Industri Sanggah Di Kecamatan Mengwi. E-Jurnal Ekonomi dan Bisnis Universitas Udayana. 7 (8) : 1927 1956, ISSN : 2337-3067.

Njoto, T, K. 2016. Pengaruh Desain Kemasan, Cita Rasa, Dan Variasi Produk Terhadap Keputusan Pembelian Konsumen Bumi Anugerah .,Performa: Jurnal Manajemen Dan Start-Up Bisnis :455 - 463.

Nicholls, A. (2008). Social entrepreneurship : New model of sustainable social change. New York : OUP Oxford, 2008

Priyandika, A,N. 2015. Analisis Pengaruh Jarak, Lama Usaha, Modal, Dan Jam Kerja Terhadap Pendapatan Pedagang Kaki Limakonveksi (Studi Kasus Di Kelurahan Purwodinatan Kota Semarang). Skripsi. Universitas Diponogoro Semarang.

Rahkadima, Y,T., Fitri, M,A., Wulandari, R,S. 2019. Penggunaan Pemasaran Online Pada Umkm Telur Asin Di Desa Kebonsari, Kabupaten Sidoarjo Prosiding Seminar Nasional Teknologi Dan Sains (SNasTekS). 18 September 2019.ISBN: 978-623-91277-6-3.

Romdonah, R., Fathoni, A., Haryono, A,T. 2015. Pengaruh Inovasi Produk, Harga Dan Brand Image Terhadap Keputusan Pembelian Sepeda Motor Honda Beat (Studi Kasus Pada Konsumen Dealer Honda Pratama Kurnia Kasih). Journal of Management. 1 (1). ISSN : 2502-7689.

Setiawan, A, T., Fauzi, A., Sanawiri, B. 2018. Pengaruh Gaya Hidup Dan Inovasi Produk Terhadap Keputusan Pembelian (Survei Pada Mahasiswa S1 Jurusan Ilmu Administrasi Bisnis Angkatan 2014/2015 Fakultas Ilmu Administrasi Universitas Brawijaya Malang Yang Membeli, Menggunakan Dan Mengetahui Smartphone Samsung Galaxy Series). Jurnal Administrasi Bisnis (JAB). 62 (1).

Setiawati, I., Widyartati, P.2017. Pengaruh Ekonomi Sosial dan Budaya

1080 
Strategi Pemasaran Online Terhadap Peningkatan Laba UMKM.Seminar Nasional dan Call for Paper 2017 Strategi Pengembangan Sumber Daya Manusia Melalui Publikasi Jurnal Ilmiah dalam Menyikapi Permenristekdikti RI No.20 Tahun 2017. 9 Mei 2017, STIE Dharmaputra,Semarang. 343.
Sukoco, A, F., Endang, M, W,. Zahroh, Z. 2015. Pengelolahan Modal Kerja Usaha Mikro Untuk Memperoleh Profitabilitas. Jurnal Administrasi Bisnis (JAB). 22 (1). 